\title{
Diversity of nitrite reductase genes (nirS) in the denitrifying water column of the coastal Arabian Sea
}

\author{
D. Amal Jayakumar ${ }^{1}$, Chris A. Francis ${ }^{1,3}$, S. Wajih A. Naqvi ${ }^{2}$, Bess B. Ward ${ }^{1, *}$ \\ ${ }^{1}$ Department of Geosciences, Princeton University, Washington Road, Princeton, New Jersey 98544, USA \\ ${ }^{2}$ National Institute of Oceanography, Dona Paula, Goa 403 004, India \\ ${ }^{3}$ Present address: Department of Geological and Environmental Sciences, Stanford University, Stanford, \\ California 94305-2115, USA
}

\begin{abstract}
Denitrification often occurs in the water column, underlying zones of intense productivity and decomposition in upwelling regions. In the denitrifying zone off the southwest coast of India, high concentrations of nitrite $(>15 \mu \mathrm{M})$ and nitrous oxide $(>500 \mathrm{nM})$ have been reported near the sediment-water interface $(<80 \mathrm{~m})$. We investigated the chemical and molecular indicators of denitrification along the southwest coast of India during the southwest monsoon season of October 2001. Nitrite reduction to nitric oxide is the key step in the denitrification pathway, and is catalyzed by the enzyme nitrite reductase, which is encoded by the genes nirS and nirK. Here we report the diversity and distribution of nirS genes in relation to nitrite and nitrate distribution in the Arabian Sea coastal denitrifying region. nirS gene fragments were PCR-amplified, cloned, and sequenced from DNA extracted from the water column. Clone libraries were also subjected to restriction fragment length polymorphism (RFLP) and rarefaction analyses. These are the first nitrite reductase sequences reported from a water column denitrifying regime. nirS was amplified from DNA extracted from all water samples in which nitrite was present at high concentrations within the low oxygen waters, but was only rarely amplified from waters containing hydrogen sulfide or from well-oxygenated waters. Phylogenetic analysis grouped 132 nirS Arabian Sea sequences into 12 major clusters. Most of the nirS sequences from the coastal water column did not show a high level of identity with other nirS sequences previously reported from marine and estuarine sediments. Identities of the Arabian Sea sequences to those in the public database ranged from 44 to $99 \%$ at the amino acid level. The dominant sequence type from 1 surface sample showed $99 \%$ identity to the nirS sequence of the cultivated denitrifier Pseudomonas aeruginosa. Rarefaction analysis, based on both sequence and RFLP data, indicated the highest diversity in a sample in which relatively high nitrite concentrations implied the presence of active denitrification, and the lowest diversity in a surface sample where nitrite was undetectable, suggesting a link between functional diversity and ecosystem chemistry.
\end{abstract}

KEY WORDS: Nitrite reductase $\cdot \operatorname{nirS} \cdot$ Denitrification $\cdot$ Arabian Sea $\cdot$ Water column Resale or republication not permitted without written consent of the publisher

\section{INTRODUCTION}

Denitrification is the principal pathway by which fixed nitrogen is removed from the marine environment. Although sedimentary denitrification is widespread in the marine ecosystem, water column denitrification occurs in only a few geographically constrained regions of the world's oceans, accounting for ca. $30 \%$ of the oceanic denitrification (Codispoti et al. 2001). In fact, the Arabian Sea, which covers only $\sim 2 \%$ of the global oceanic area, accounts for ca. $20 \%$ of oceanic denitrification and, hence, plays a major role in the marine nitrogen budget (Codispoti et al. 2001). Moreover, these denitrifying zones are major sources to the atmosphere of nitrous oxide, which is a potent greenhouse gas that is also involved in the destruction of the ozone layer (Crutzen 1979, Lashof \& Ahuja 1990, Waibel et al. 1999).

Water column denitrification in the Arabian Sea occurs in 2 geographically distinct locations, one within the perennial oxygen minimum zone (OMZ) in 
the open Arabian Sea, and the other within the seasonal OMZ along the shelf of the southwest coast of India. In the open Arabian Sea, the development of oxygen-deficient conditions leading to denitrification is attributed to excessive oxygen consumption, combined with the low oxygen content of waters responsible for renewal (Swallow 1984, Naqvi 1987). In the coastal OMZ, denitrification occurs seasonally, centered around the southwest monsoon season (May to October), when intensive upwelling takes place along the entire shelf of the southwest coast of India, injecting nitrate-rich waters into the photic layers. The intense productivity that ensues leads to $\mathrm{O}_{2}$ depletion and then to denitrifying conditions in the subsurface shelf waters (Naqvi et al. 2000).

Due to the significance of this environment to the global nitrogen cycle, and the potential sensitivity of coastal denitrification to environmental conditions and global change (Naqvi et al. 2000), it is important to understand the microbial ecology of the system. This includes the community structure and diversity of microorganisms responsible for sustaining this nitrogen cycle, especially organisms responsible for denitrification. Our knowledge of the microbial communities responsible for denitrification in the pelagic zone is very limited. Because the capability for denitrification occurs in a wide range of taxonomic groups, including more than 50 genera of Bacteria and Archaea (Zumft 1997) that include many non-denitrifying metabolic types, a 16S rRNA-based approach to study denitrifying microbes in the environment is not appropriate. Instead, a PCR-based approach using primers targeting the key functional genes involved in denitrification is more useful for investigating the diversity of microbes responsible for this process. We recognize that there is more to diversity than numbers of 'species' in an environment, but here we use diversity to represent species richness and phylogenetic variation, as is the current convention in microbial ecology.

The key step in the denitrification pathway is the reduction of nitrite to nitric oxide by nitrite reductase (Zumft 1997), the first step to distinguish denitrifying bacteria (which produce gas) from nitrate-respiring bacteria (here defined as those which reduce nitrate to nitrite but do not produce gas). There are 2 types of respiratory nitrite reductase: the copper-containing nirK and the cytochrome $c d_{1}$-containing nirS. nirK is present in a wide range of taxonomically unrelated groups, while nirS has so far been reported only within the Proteobacteria. The 2 reductases are apparently functionally and physiologically equivalent (Glockner et al. 1993, Zumft 1997). Recent studies have explored nitrite reductase gene diversity in Pacific Northwest marine sediments (Braker et al. 2000), acid forest soil (Rosch et al. 2002), forested upland and wetland soils
(Prieme et al. 2002), sediments of the River Colne estuary (Nogales et al. 2002) and contaminated groundwater (Yan et al. 2003). In this study, we focus on the diversity and distribution of the nitrite reductase gene nirS in order to relate its diversity to nitrite and nitrate distribution in the water column of the coastal denitrifying region of the Arabian Sea.

\section{MATERIALS AND METHODS}

Sample collection. Samples were collected during a cruise on the coastal RV 'Sagar Sukti' in October 2001 (Fig. 1) from 3 stations (G5, G8, V4). The maximum depth at these stations was 28, 65 and $85 \mathrm{~m}$, respectively. Each sample is identified by a letter, which identifies the nearest shore station $(\mathrm{G}=\mathrm{Goa}, \mathrm{V}=$ Vengurla), followed by numerals (the first digit is the station number, the second and third digits the sample depth) (e.g. sample G857 = off Goa, Stn 8, sample depth 57 m). Water samples were collected using a 51 Niskin bottle mounted on a hydrography wire. Because large changes in redox conditions are generally observed within small depth intervals, all hydrographic and chemical measurements were made on the same Niskin sample from which DNA samples were collected. Temperature was measured with reversing thermometers mounted on the Niskin bottles. Samples were also collected for dissolved oxygen, sulfide, nitrate, and nitrite analyses. Water samples for DNA extractions were collected in acid-washed 21 plastic bottles and stored $(<2 \mathrm{~h})$ at $4{ }^{\circ} \mathrm{C}$ before filtration onto Sterivex capsules $(0.2 \mu \mathrm{M}$ filter, Millipore) using a peristaltic pump. The volume of water $(0.9$ to 2.2 l) filtered through each

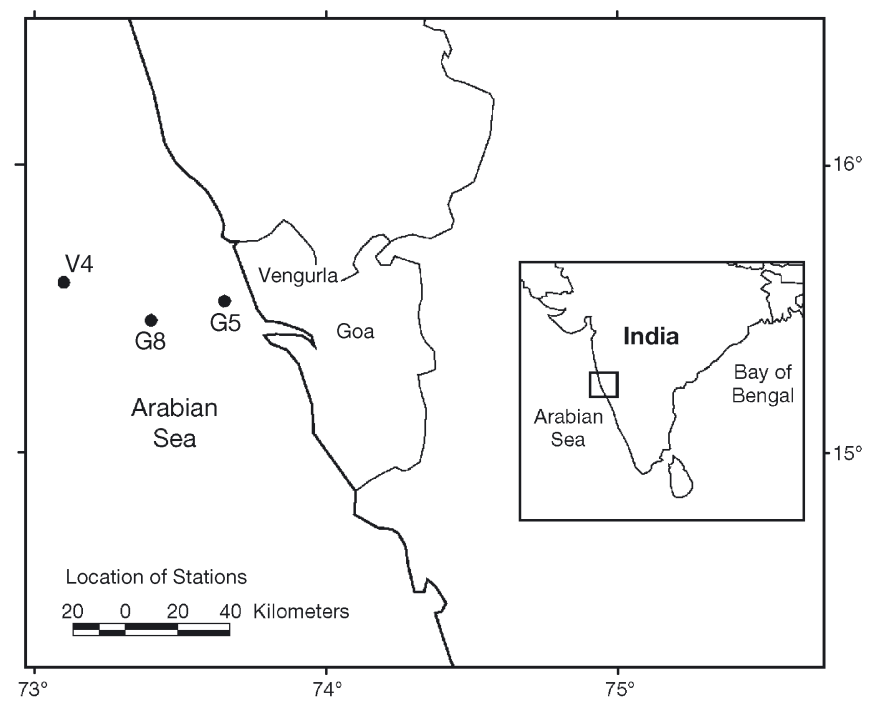

Fig. 1. Sampling locations for the coastal RV 'Sagar Sukti' cruise in October 2001 
Sterivex varied with the turbidity and amount of particulate matter in the samples (Table 1). Immediately following filtration, excess water was removed from the Sterivex using a syringe, and the capsule was capped using sealing clay and a luer lock cap, packed in polypropylene bags, and immediately frozen in liquid nitrogen. The samples were stored in liquid nitrogen, on dry ice, or in a $-80^{\circ} \mathrm{C}$ freezer until DNA extraction.

Analytical techniques. Routine on-board analyses of nutrients, salinity and dissolved $\mathrm{O}_{2}$ were performed within a few hours of collection. Dissolved oxygen concentration was determined by the autotitration Winkler method (Carpenter 1965). A Skalar Autoanalyser was used to analyze nutrients (Grasshoff et al. 1983) and salinity measurements were made with a Guildline Autosal.

DNA purification, cloning and sequencing. DNA was extracted from Sterivex filters using the PUREGENE Genomic DNA Isolation Kit (Gentra Systems) using conditions specified by the manufacturer. The precipitated DNA was hydrated in $50 \mu \mathrm{l}$ sterile water. All DNA samples were first subjected to PCR amplification using universal eubacterial 16S rRNA primers EUB1 and EUB2 (5' positions 9 to 27 and $3^{\prime}$ positions 1525 to 1542 in the Escherichia coli sequence) (Liesack et al. 1991) to confirm that the DNA was of PCR quality. nirs genes were amplified using PCR conditions and Primers nirS1F and nirS6R of Braker et al. (1998). PCR amplifications were performed in a final volume of $50 \mu \mathrm{l}$ in a thermocycler (MJ Research). The amplified products were visualized after electrophoresis in $1 \%(\mathrm{w} / \mathrm{v})$ agarose gels and staining with ethidium bromide. Four replicate PCR reactions of each sample were pooled and gel purified using the QIAquick Gel
Extraction Kit (Qiagen). The products were cloned using the TOPO-TA cloning kit (Invitrogen). In all, 96 white colonies were picked from the clone library generated from each sample (G840, G857, V400 and V483), and then incubated in 96-well plates overnight at $37^{\circ} \mathrm{C}$ in $150 \mu \mathrm{l}$ Luria-Bertani (LB) medium containing $7.5 \%$ glycerol and, after PCR screening, plates were stored frozen at $-80^{\circ} \mathrm{C}$. Each clone was PCR amplified with T7-M13 primers and the products were used as templates for cycle sequencing, using either M13 (reverse) or T7 primers and the Big Dye ${ }^{\mathrm{TM}}$ V.3.0 terminator chemistry (Applied Biosystems) on an ABI 310 automated DNA sequencer (Applied Biosystems). Once confirmed to contain nirS fragments, a minimum of 25 randomly picked T7-M13 PCR-amplified products from each library were sequenced from both ends using both T7 and M13 (reverse) primers on an ABI 3100 automated DNA sequencer (Applied Biosystems).

Restriction fragment length polymorphism (RFLP) analysis of nirS clones. Restriction digestions of T7-M13 PCR products $(3 \mu \mathrm{l})$ were performed in $10 \mu \mathrm{l}$ reactions, containing $1 \mathrm{U}$ each of the enzymes HaeIII and MspI (Roche Diagnostics), $1 \mu \mathrm{l}$ buffer and incubated for $3 \mathrm{~h}$ at $37^{\circ} \mathrm{C}$. RFLP patterns were visualized after electrophoresis at $60 \mathrm{~V}$ in $2 \%(\mathrm{w} / \mathrm{v})$ agarose gels for $2 \mathrm{~h}$ and staining with ethidium bromide. Representatives of each RFLP pattern generated from the clone libraries were partially sequenced to confirm that these were nirS products, but not all clones corresponding to each of these RFLP patterns were sequenced from both ends. Hence, nirS sequences representing some of the RFLP patterns were not included in the subsequent phylogenetic analysis.

Table 1. Sample information. Station locations shown in Fig. 1. Success (+) and failure (-) of PCR amplification with the 2 primer sets (16S and nirS) are indicated, along with the number of nirS clones from each depth that were sequenced and analyzed by RFLP (restriction fragment length polymorphism)

\begin{tabular}{|c|c|c|c|c|c|c|c|c|c|}
\hline Stn & $\begin{array}{l}\text { Depth } \\
\text { (m) }\end{array}$ & $\begin{array}{c}\text { Volume } \\
\text { filtered (ml) }\end{array}$ & $\begin{array}{l}16 \mathrm{~S} \\
\mathrm{PCR}\end{array}$ & $\begin{array}{l}\text { nirs } \\
\text { PCR }\end{array}$ & $\begin{array}{c}\text { No. of nirS } \\
\text { clones (sequence) }\end{array}$ & $\begin{array}{c}\text { No. of nirS } \\
\text { clones (RFLP) }\end{array}$ & $\begin{array}{l}\mathrm{NO}_{2}^{-} \\
(\mu \mathrm{M})\end{array}$ & $\begin{array}{c}\mathrm{T} \\
\left({ }^{\circ} \mathrm{C}\right)\end{array}$ & Salinity \\
\hline \multirow[t]{5}{*}{ G8 } & 10 & 1050 & + & - & 0 & 0 & 0.0 & 25.92 & 35.78 \\
\hline & 20 & 1140 & + & - & 0 & 0 & 0.0 & 20.70 & 35.44 \\
\hline & 30 & 1140 & + & - & 0 & 0 & 0.0 & 20.13 & 35.25 \\
\hline & 40 & 1090 & + & + & 36 & 84 & 6.7 & 20.13 & 35.57 \\
\hline & 57 & 1150 & + & + & 36 & 82 & 7.3 & 19.95 & 35.65 \\
\hline \multirow[t]{5}{*}{ G5 } & 00 & 1050 & + & - & 0 & 0 & 0.5 & 23.50 & 35.07 \\
\hline & 05 & 1160 & + & - & 0 & 0 & 0.4 & 23.01 & 35.06 \\
\hline & 11 & 900 & + & - & 0 & 0 & 0.0 & 21.28 & 35.32 \\
\hline & 18 & 1060 & + & - & 0 & 0 & 0.0 & 20.70 & 35.42 \\
\hline & 25 & 1150 & + & - & 0 & 0 & 0.0 & 20.60 & 35.31 \\
\hline \multirow[t]{5}{*}{ V4 } & 00 & 2100 & + & + & 26 & 65 & 0.0 & 28.70 & 36.04 \\
\hline & 40 & 2020 & + & + & 0 & 0 & 0.3 & 20.00 & 35.54 \\
\hline & 50 & 2200 & + & + & 0 & 0 & 1.0 & 19.80 & 35.69 \\
\hline & 60 & 2000 & + & + & 0 & 0 & 1.5 & 19.60 & 35.72 \\
\hline & 83 & 1900 & + & + & 34 & 67 & 1.9 & 19.50 & 35.39 \\
\hline
\end{tabular}


Sequence and rarefaction analysis. Sequences ( 890 bp) were edited and assembled into single consensus sequences using Sequencher 4.1 ${ }^{\mathrm{TM}}$ (Gene Codes). These consensus sequences were then translated to amino acid sequences and aligned using ClustalX (Thompson et al. 1997). After removing gaps, a neighbor-joining tree was produced from the alignment using distance matrix methods (PAUP 4.0, Sinauer Associates). Bootstrap analysis was used to estimate the reliability of phylogenetic reconstruction (100 replicates). Rarefaction statistics (Heck et al. 1975) were computed using the software Analytic Rarefaction 1.3 $3^{\mathrm{TM}}$ (Holland 2001). For this analysis, operational taxonomic units (OTUs) were defined in 2 different ways: (1) distinct RFLP patterns; and (2) sequences differing by $>5 \%$ at the DNA level.

Sequence accession numbers. The nirS sequences reported in this study have been deposited in GenBank under accession numbers AY336801 to AY336932, and specific clones are identified in Fig. 3.

\section{RESULTS AND DISCUSSION}

\section{Development of denitrification in the study area}

The general circulation during the southwest monsoon season is clockwise in the Arabian Sea and, hence, along the west coast of India the surface flow is equatorward. The source of upwelled water is the poleward undercurrent (Shetye et al. 1990). The upwelling water is low in oxygen, but relatively high in nitrate, as it comes from the oxygen-depleted middepth of the Arabian Sea. The nutrient-rich waters promote very high primary production, mainly within the pycnocline (Jayakumar et al. 2001), and the large biological consumption of oxygen during decomposition of the organic matter, derived from high productivity, leads to denitrification and sulfate reduction in the coastal region. Because of these widespread suboxic and anoxic conditions, very high accumulations of nitrous oxide and hydrogen sulfide occur in this region (Naqvi et al. 2000). Denitrifying zones in the subsurface hypoxic layers of the Eastern Tropical Pacific Ocean and the Arabian Sea are recognized by their secondary nitrite maxima (SNM), which also have high bacterial abundances (Spinrad et al. 1989, Ward et al. 1998). The depth of the SNM is highly correlated with the depth of the particle maxima in oxygen minimum zones of these regions (Naqvi et al. 1993). Thus, although direct real-time measurements of denitrification rates are not usually available, the hydrographic and chemical signatures (particulate maxima, nitrite concentration maxima, and maxima in bacterial numbers) are conventionally interpreted to imply active denitrification (Naqvi et al. 1993). Thus, we focused on comparisons of sites within the coastal Arabian Sea system, where these indicators implied variable levels of denitrification activity. While nitrite can also be produced either as a result of assimilatory reduction of nitrate by phytoplankton or during the oxidation of ammonia (nitrification), observations in the Indian coastal waters since 1997 (Naqvi et al. 2000) have shown that high concentrations $(>1 \mu \mathrm{M})$ of nitrite invariably occur when the water has been almost completely depleted of dissolved oxygen, and the nitrate concentrations are much below levels that might be expected $(>20 \mu \mathrm{M})$ in non-reducing low-oxygen environments. This implies that dissimilatory nitrate reduction is likely the dominant process responsible for the observed build-up of nitrite.

Samples for this study were selected on the basis of the water column chemistry (Fig. 2), from stations where varying levels of denitrification were indicated by high (Stn G8) or low (Stn V4) nitrite concentrations, and where late or post-denitrification conditions were indicated by the presence of sulfide, and the absence of oxidized forms of nitrogen (Stn G5; $5 \mu \mathrm{M} \mathrm{H}_{2} \mathrm{~S}$ was measured at this station). The temperature ranged between 19.5 and $28.7^{\circ} \mathrm{C}$, and salinity between 35.06 and 36.04 in the water columns of the sampling locations (Table 1). Temperature and salinity were low in the mid-depth and bottom water samples (G840, G857, and V483), and high at the surface (V400). However, the range in temperature $\left(1^{\circ} \mathrm{C}\right)$ and salinity $(0.5)$, for the samples from which most of the sequence information was obtained (G840, G857, and V483) was minimal.

\section{PCR amplification of Arabian Sea DNA extracts}

All the DNA samples were PCR amplified using the 16S rRNA primers, but some samples could not be amplified using the nirS primers (Table 1). All DNA samples extracted from low oxygen waters containing high nitrite concentrations could be amplified using the nirS primers. Results from samples collected from oxic waters where nitrite was low $(<0.5 \mu \mathrm{M})$ or undetectable, and samples collected from sulfide bearing waters, were variable. For example, DNA extracts from V400, a sample from the surface where nitrite was undetectable, could be amplified, while surface and 5 m samples (G500 and G505) containing only traces of nitrite $(<0.5 \mu \mathrm{M})$ could not be amplified.

\section{nirS phylogenetic relationships}

nirS sequences were obtained from Stns G8 (at depths where $\mathrm{NO}_{2}^{-}>6 \mu \mathrm{M}$ ) and V4 (all depths, $\mathrm{NO}_{2}{ }^{-}<2 \mu \mathrm{M}$ ). 

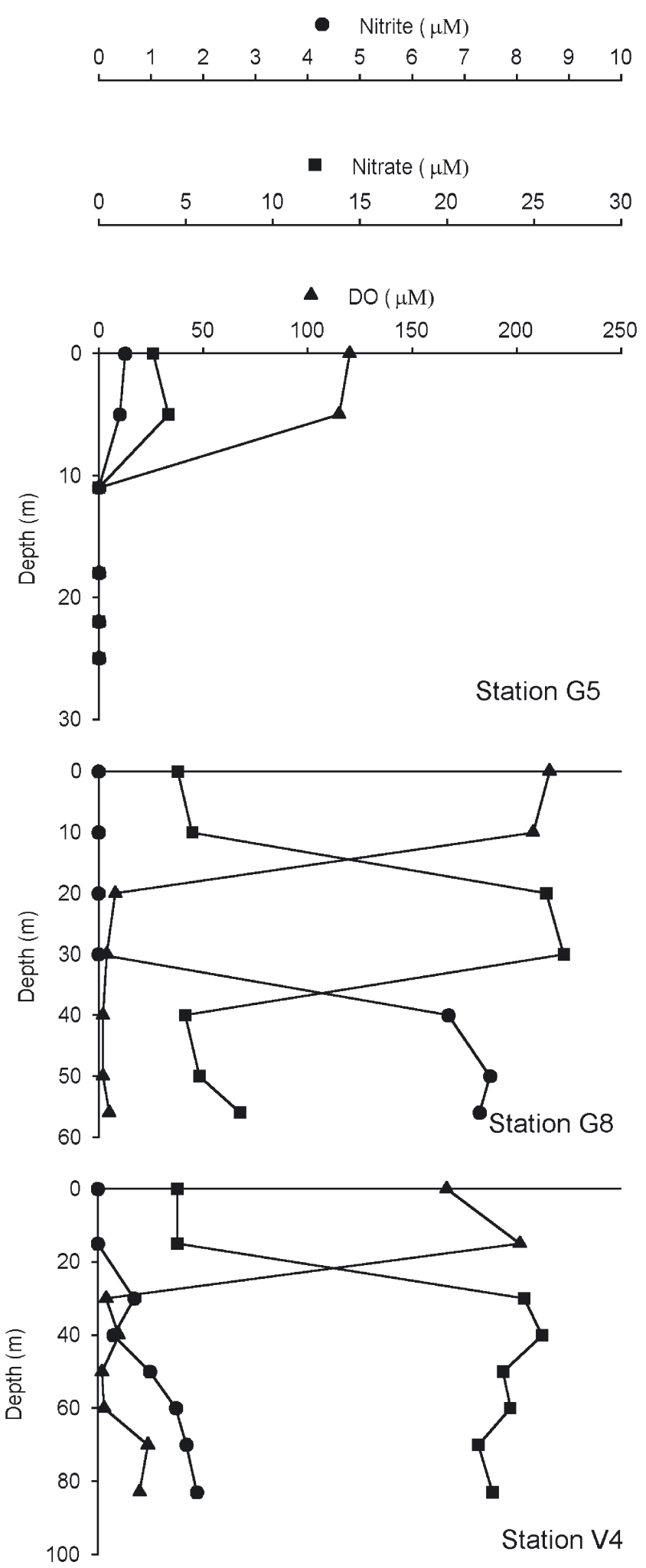

Fig. 2. Distribution of dissolved oxygen (DO; $\mu \mathrm{M})$, nitrite $(\mu \mathrm{M})$ and nitrate $(\mu \mathrm{M})$ at Stns G5, G8, and V4. Samples G840 and G857 are from Stn G8, from 40 and $57 \mathrm{~m}$ depths, respectively, and Samples V400 and V483 are from Stn V4, from the surface and $83 \mathrm{~m}$ depth, respectively
Phylogenetic analysis revealed that the greatest nirS diversity was found in samples where the concentration of $\mathrm{NO}_{2}^{-}$was higher than $1.5 \mu \mathrm{M}$, but lower than $6 \mu \mathrm{M}$. The identities of these sequences to those of sequences in the database ranged from 44 to $99 \%$ at the amino acid level. The nirS sequences from these samples could be grouped into 12 major clusters, 7 of which were phylogenetically distinct from database sequences (Fig. 3). Not all nirS sequences from the database (e.g. groundwater sequences, Yan et al. 2003) were included in our analysis shown in Fig. 3, as many of these studies have reported only a shorter region of the nirS sequence.

Most (58\%) of the sequences fell into 3 distinct clusters (Clusters II, III and VIII) (Fig. 3). Clusters II, III, IV, $\mathrm{V}, \mathrm{XI}$ and XII contained representatives from both Stns G8 and V4, but only from depths where nitrite was present. Cluster VII contained only sequences from Sample V483. Cluster VIII contained sequences from both depths of Stn V4 (Samples V400 and V483), and did not contain any sequences from Stn G8 (Samples G840 and G857). Cluster IX included sequences from both depths at Stn V4 and 1 sequence from Sample G840. Cluster VIII contained the majority (23 of 26) of the sequences from Sample V400. Many of the sequences in Cluster VIII were virtually identical to the nirS sequence of the cultivated denitrifier Pseudomonas aeruginosa, showing $>99 \%$ identity at the DNA and amino acid level. Sequences with such striking similarity to the $P$. aeruginosa nirS gene were also reported by Yan et al. (2003) from a uranium- and nitrate-contaminated groundwater environment. A nirS environmental clone, exhibiting close identity to a cultured denitrifier species, was also observed in a recent study of the River Colne estuary sediments, in which virtually identical nirs sequences were obtained from a Flavobacterium isolate and from 2 RT-PCR mRNA clones (Nogales et al. 2002). Whether these P. aeruginosa-like nirS sequences actually correspond to $P$. aeruginosa-like bacteria, or are the result of horizontal gene transfer to an unrelated organism, requires cultivation studies.

Sequences from samples whose chemical characteristics (e.g. high nitrite concentration) were indicative of more intense denitrification are distributed throughout the tree, but in discrete clusters (Fig. 3). Using high nitrite concentration as a measure of the intensity of denitrification, the upper portion of the tree brackets the sequences from the more intense denitrification zones, and also contains a few clones from Sample V483, but not Sample V400. The cluster containing nirs sequences from several cultivated denitrifying organisms (the cluster between Clusters V and VI in Fig. 3) does not contain any environmental clones from the present study or from the Pacific Northwest marine 


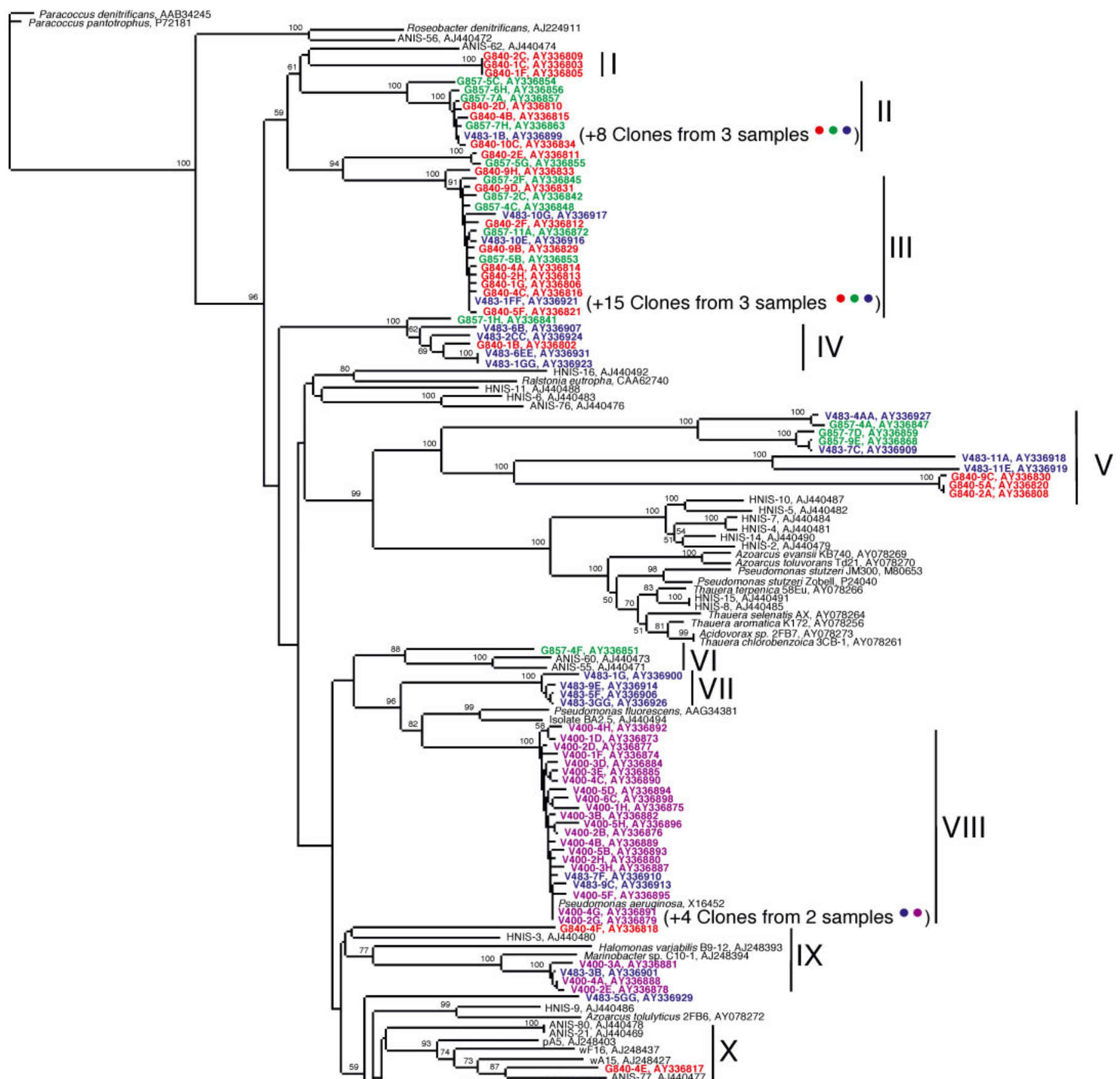

Fig. 3. Phylogenetic tree of translated nirS sequences (partial, 270 amino acids) from the water column off the southwest coast of India, with Paracoccus denitrificans and Paracoccus pantotrophus as the outgroups. Bootstrap values (>50\%) are indicated at the branch points. Phylogenetic positions of nirs clones from the present study are in colors (Red: G840, Green: G857, Pink: V400, Blue: V483; see 'Sample collection' for station codes), and database sequences in black. Clusters are marked in Roman numerals. Sequences which were detected numerous times are indicated (number of clones) 
sediments (Braker et al. 2000), but does contain sequences from River Colne estuary sediments (Nogales et al. 2002). Future cultivation work from these waters would reveal the extent to which these cloned nirS sequences correspond to cultivable bacteria.

Cluster I contained a nirS sequence from River Colne estuary sediments (Nogales et al. 2002) and, in Cluster VI, 1 sequence from Sample G857 grouped together with sequences from River Colne estuary sediments. Cluster IX, which contained sequences from samples G840, V400 and V483, also contained sequences from 2 marine denitrifying isolates, Marinobacter sp. C10-1 and Halomonas variabilis B9-12, from Pacific Northwest marine sediments (Braker et al. 2000) and 1 nirs RT-PCR clone from the River Colne estuary sediments (Nogales et al. 2002).

Ten of the sequences (Cluster V) were quite distinct from all other known nirS sequences. BLAST searches confirmed that these were distantly related nirS sequences, with the most divergent of them showing only $44 \%$ identity, at the amino acid level, to its closest relative, Ralstonia eutropha. These 10 sequences were so divergent that it was not possible to reasonably align them over the entire $890 \mathrm{bp}$ fragments at the DNA level. However, these sequences could be aligned at the amino acid level, and formed a distinct phylogenetic cluster (Cluster V).

Six clusters in Fig. 3 contained sequences from the nitrite-bearing waters of both Stns G8 and V4. All the sequences from Sample V400 fell into 2 clusters (Clusters VIII and IX), which included sequences from Sample V483 and 1 sequence from Sample G840 (Cluster IX), which all had only $74 \%$ identity to the closest sequence from Sample V400. Thus, it appears that although there is some overlap between the types of nirS sequences found at Stns G8 and V4, certain sequence types are unique to Stn V4. This coastal OMZ is separated from the perennial OMZ of the open Arabian Sea by a narrow band of coastal current, which is ca. $200 \mathrm{~km}$ wide in this region at this time of the year (Shetye et al. 1990), and there appears to be a break in denitrification parameters at ca. $200 \mathrm{~km}$ from the coast, separating the coastal denitrification region from the open ocean denitrification zone (Jayakumar 1999). Stn V4 is ca. $90 \mathrm{~km}$ from the coast and, therefore, would clearly represent the coastal denitrification zone. Future studies will investigate possible relationships between the nirS diversity in the open Arabian Sea OMZ and the coastal OMZ.

In Cluster $\mathrm{X}$, which is supported by high bootstrap values, 1 sequence from sample G840 (G840-4E) groups together with nirS sequences from Washington coast and Puget Sound sediments (Braker et al. 2000), as well as mRNA clones from River Colne estuary sedi- ments (Nogales et al. 2002). Cluster XII, also supported by high bootstrap values, contained clones from Samples G840, G857 and V483, all of which had high nitrite concentrations, as well as Clone pB20 from Puget Sound sediments (Braker et al. 2000). Clusters X, $\mathrm{XI}$ and XII, together with sequences from Pacific Northwest and River Colne estuary sediments at the bottom part of the tree, represent a diverse group of nirS types distributed widely in geographically different marine and estuarine environments, but they are not well represented by cultivated strains. The 1 cultured species Azoarcus tolulyticus 2FB6, within this overall cluster, was a strain isolated from agricultural soil (Song \& Ward 2003), but different strains (2FB2 and 4 FB10) of this same species have also been isolated from estuarine sediments (Song et al. 2000).

In spite of the similarities between some of the Arabian Sea nirS sequences and other reported marine and estuarine sedimentary sequences, 2 of the 3 dominant clusters (Clusters II and III) of sequences from the water column do not show high similarities to other published nirS sequences. These Cluster II and III sequences were derived from the samples with the strongest denitrification signatures (e.g. highest nitrite and oxygen depletion). The novelty of sequences in these samples could be due to geographical distance between the Arabian Sea site and the previously studied regions. Alternatively, it might imply that different denitrifying communities are found in the water column versus sedimentary denitrification regimes. Future examination of sediment samples from the coastal Arabian Sea will help address this issue.

\section{RFLP analysis of the nirS clones}

A total of 298 nirS clones were subjected to RFLP analysis, which revealed a total of 27 different patterns (Fig. 4). The clones within several of the 12 major clusters (Fig. 3) had similar RFLP patterns. However, in some cases, smaller sub-groups emerged within a cluster, and in the sub-groups the RFLP patterns were identical. For example, Cluster XII, which contained a number of sub-groups, included many different patterns, but within each sub-group, the patterns were identical (Fig. 3). This analysis also revealed that 1 pattern (Pattern No. 2 in Fig. 4), represented by Cluster III, was dominant in Samples G857 and G840, and also appeared rarely in Sample V483, but not in Sample V400. Half of the clones analyzed (51 and 53\% in G857 and G840, respectively) consisted of Pattern No. 2, while in Sample V483, only $7.5 \%$ of the clones consisted of this pattern. Sample V483 was the only sample that did not show any clear indication of a dominant pattern. 


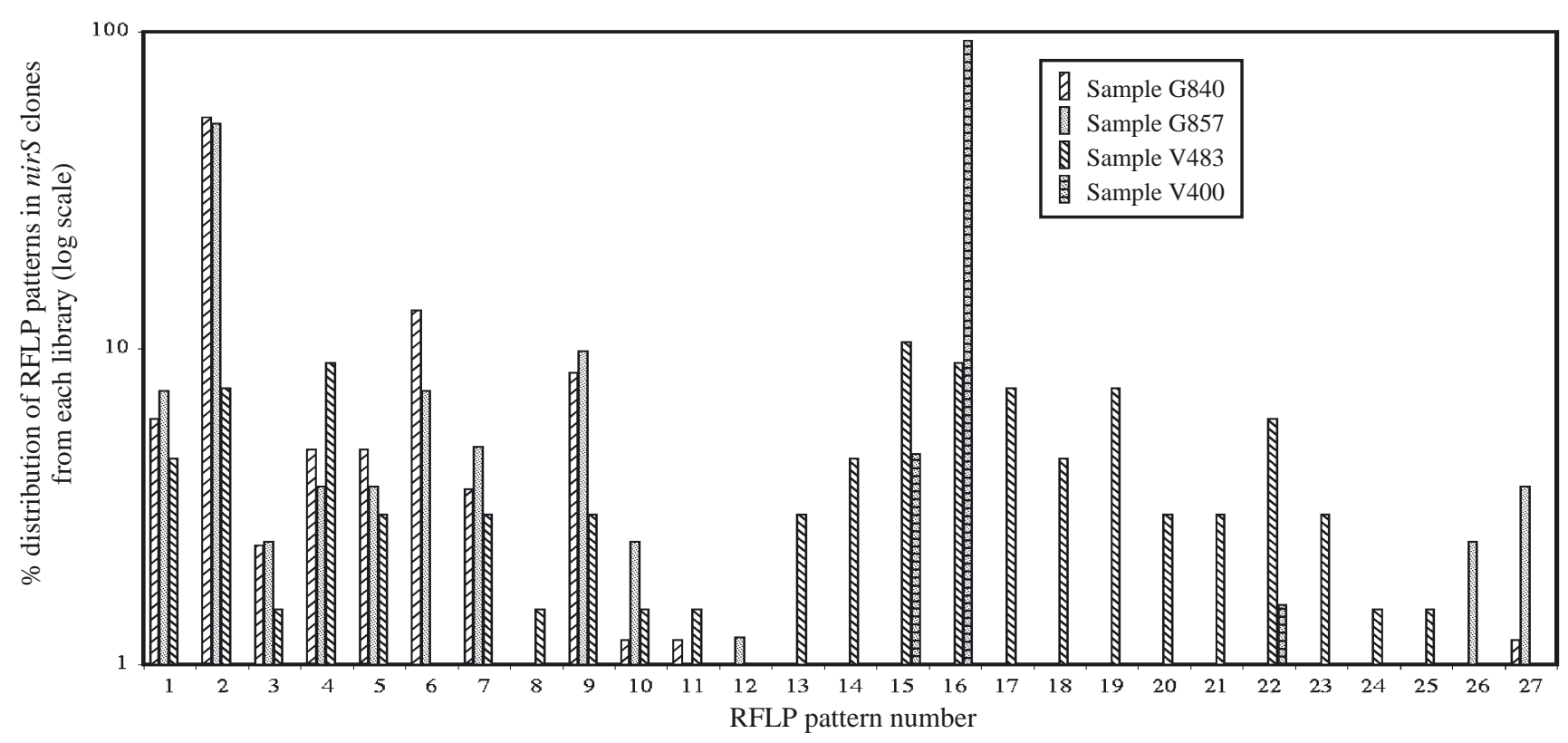

Fig. 4. Distribution of restriction fragment length polymorphism (RFLP) patterns in the clone libraries. See 'Sample collection' for station and sample codes

In Sample V400, only 3 different patterns were observed, and 1 pattern (Pattern No. 16) accounted for $94 \%$ of the clones. This RFLP pattern is represented by Cluster VIII (Fig. 3), which contains sequences that were virtually identical to the nirS sequence of the cultivated denitrifier Pseudomonas aeruginosa. Although RFLP Pattern No. 16 was dominant in the welloxygenated surface layer, where it is unlikely to be denitrifying, this pattern accounted for only $9 \%$ of the clones within the OMZ of the same station, where denitrification was probably occurring. The nirs clone library from sample V400 had the lowest diversity, possibly indicating that a change in environmental conditions, from an active denitrification zone within a suboxic environment, to a welloxidized environment, led to the reduction in diversity. All the patterns observed in Sample V400 were also found in Sample V483, but not in the 2 samples from Stn G8.

\section{Rarefaction analysis}

To investigate the relationship between sampling effort and diversity in terms of different RFLP patterns, rarefaction analysis was performed based on the cumulative number of distinct RFLP patterns relative to the number of clones screened (Fig. 5). Rarefaction compares observed richness among clone libraries that have been unequally sampled, and is obtained by averaging randomizations of the observed accumulation curve (Heck et al. 1975). The same kind of analysis was also performed on the sequence data, using a $5 \%$ difference in DNA sequence identity in defining a unique OTU. Overall, the results of RFLP analysis of 298 clones were consistent with the sequence analysis

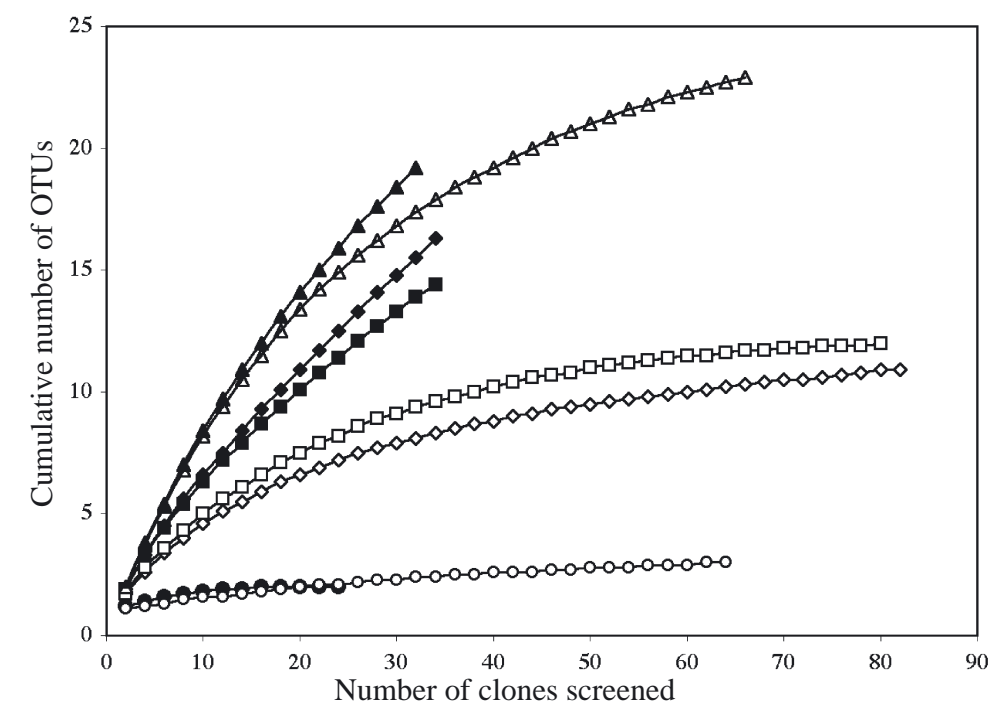

Fig. 5. Rarefaction curves generated from restriction fragment length polymorphism (RFLP) patterns (open symbols) and nirS sequences (filled symbols); G840 (diamonds), G857 (squares), V483 (triangles), V400 (circles) (see 'Sample collection' for station and sample codes); $5 \%$ difference was the cutoff limit for the sequence-defined operational taxonomic units (OTUs) 
of 132 nirS clones; both approaches indicated that Sample V483 had the highest diversity and Sample V400 the lowest. However, Samples G857 and G840 exhibited greater diversity (i.e. less curvature) based on the clone library sequences than the RFLP analysis, and their relative levels were reversed. While RFLP analysis suggests that additional analysis of clones would be unlikely to result in the identification of novel nirS RFLP patterns, sequence analysis suggests that the diversity has not yet been saturated within 3 of the 4 libraries.

\section{Diversity in relation to the state of denitrification}

Stn G8 appears to be at a more intense stage of denitrification than Stn V4, based on the nitrite and nitrate distributions (Fig. 2, Table 1). Based on the hydrography of the area, we can infer a time series in the development of denitrification activity among our sample locations. Within the OMZ of Stn G8, almost all the nitrate has been reduced to nitrite or further, implying a late stage in the development of denitrification. By contrast, Stn V4 appears to represent an earlier stage in the process. Although it has low oxygen, nitrate has been depleted by only a few micromoles (more than $17 \mu \mathrm{M}$ nitrate remained that could possibly be denitrified). Nitrite and oxygen concentrations were both higher in the earlier stages. The initial concentration of nitrate appears to have been the same at both these locations ( 20 $\mu \mathrm{M}$ at the oxic depth). The clone libraries (which, within the limits of PCR, represent a first level of describing community structure) imply that diversity is very high in the initial stages of denitrification (Sample V483), but eventually a few particular clones rise to dominance, as seen in Samples G840 and G857. Although there were more than 23 different RFLP patterns in Sample V483, 6 different patterns were more common than the rest, each of them comprising 7.5 to $10.5 \%$ of the total, which includes the Pseudomonas aeruginosa type (RFLP Pattern No. 16) and the dominant type in Samples G840 and G857 (RFLP Pattern No. 2).

Although the surface sample from Stn V4 (Sample V400) had no traces of nitrite, nirS could be amplified from this sample. The oxygen concentration in this sample was lower than the sample just below it, suggesting that this parcel of water had recently upwelled to the surface from the $\mathrm{OMZ}$, and had lost its nitrite through oxidation and/or uptake in the photic environment. Due to the complex hydrography of the region, the oxygen-depleted upwelled water, usually kept a few meters below the surface by the warmer, lower salinity lens, reaches the surface and becomes oxygenated only intermittently. Mixing across the pycno- cline results from turbulence caused by winds and tides. The time elapsed between a parcel of water initially experiencing suboxic conditions and subsequently being reoxygenated is probably on the order of a few days, due to the light winds that are characteristic of the period of our observations. This time was probably long enough for a shift in the denitrifier community to result from differential growth of different members of the community. Thus, when the environmental conditions revert from suboxic to oxic again (Sample V400), one dominant group emerges (accounting for $>94 \%$ of clones in the clone library), but this dominant group eventually fades away to undetectable levels, as observed in the other well-oxygenated surface samples. With intensification of the suboxic conditions leading to sulfate reduction (as seen in Stn G5), denitrifiers were again below our detection limit.

Thus, these data suggest a relationship between the time-course of development of seasonal coastal denitrification and the structure of the denitrifier assemblage. The community structure changed in both the level of diversity and the composition of the assemblage, over a depth range of a few meters and an inferred time scale of days to weeks. More spatial and temporal data over the course of the development of the denitrification regime are required to substantiate a successional pattern. This analysis, based on DNA rather than RNA, cannot be used to infer activity of the bacterial assemblage. The patterns detected in DNA sequences may, however, reflect the result of differential growth (and cell number increase) of different components of the community as it experiences different stages in the development of denitrifying conditions. At the relatively high temperatures of this environment, significant shifts in community composition could easily result from rapid cell divisions of microbes whose growth is favored under suboxic conditions. Thus, diversity analysis reflects changes in community composition over the course of a few days or weeks (the time scale of development of denitrifying conditions along the shelf). However, a direct link to active denitrification awaits investigation of mRNA levels and gene expression or enzyme activities. Future analysis of the expression of nirS genes would help elucidate the relationships between genetic diversity, community structure, and actual denitrification activity.

Acknowledgements. This research was supported by NSF (CHE98-10248). We thank Dr. E. Desa, Director of the National Institute of Oceanography, for his support and providing us with the ship time, and we express our gratitude to the other participants of the cruise, including Dr. M. S. S. Shailaja, Ms. H. Naik and Dr. P. V. Narvekar for help rendered during sampling. C.A.F. was supported in part by an NSF Postdoctoral Research Fellowship in Microbial Biology. 


\section{LITERATURE CITED}

Braker G, Fesefeldt A, Witzel KP (1998) Development of PCR primer systems for amplification of nitrite reductase genes (nirK and nirS) to detect denitrifying bacteria in environmental samples. Appl Environ Microbiol 64:3769-3775

Braker G, Zhou J, Wu L, Devol AH, Tiedje JM (2000) Nitrite reductase genes (nirK and nirS) as functional markers to investigate diversity of denitrifying bacteria in Pacific northwest marine sediment communities. Appl Environ Microbiol 66:2096-2104

Carpenter JH (1965) The Chesapeake Bay Institute technique for the Winkler dissolved oxygen method. Limnol Oceanogr 10:141-143

Codispoti LA, Brandes JA, Christensen JP, Devol AH, Naqvi SWA, Paerl HW, Yoshinari T (2001) The oceanic fixed nitrogen and nitrous oxide budgets: moving targets as we enter the anthropocene? Sci Mar 65:85-105

Crutzen PJ (1979) The role of $\mathrm{NO}$ and $\mathrm{NO}_{2}$ in the chemistry of the troposphere and stratosphere. Annu Rev Earth Planet Sci 7:443-472

Glockner AB, Jüngst A, Zumft WG (1993) Copper-containing nitrite reductase from Pseudomonas aureofaciens is functional in a mutationally cytochrome $\mathrm{cd}_{1}$-free background (NirS ${ }^{-}$) of Pseudomonas stutzeri. Arch Microbiol 160: $18-26$

Grasshoff K, Ehrhardt M, Kremling K (1983) Methods of seawater analysis. Verlag Chemie, Weinheim

Heck KL, Belle GV, Simberloff D (1975) Explicit calculation of the rarefaction diversity measurement and the determination of sufficient sample size. Ecology 56:1459-1461

Holland SM (2001) Analytic rarefaction 1.3. University of Georgia, Athens, GA

Jayakumar DA (1999) Biogeochemical cycling of methane and nitrous oxide in the northern Indian Ocean. PhD thesis, Goa University

Jayakumar DA, Naqvi SWA, Narvekar PV, George MD (2001) Methane in coastal and offshore waters of the Arabian Sea. Mar Chem 74:1-13

Lashof DA, Ahuja D (1990) Relative contributions of greenhouse gas emissions to the global warming. Nature 344 : 529-531

Liesack W, Weyland H, Stackerbrandt E (1991) Potential risks of gene amplification by PCR as determined by $16 \mathrm{~S}$ rDNA analysis of a mixed-culture of strict barophilic bacteria. Microb Ecol 21:191-198

Naqvi SWA (1987) Some aspects of the oxygen-deficient conditions and denitrification in the Arabian Sea. J Mar Res 49:1049-1072

Naqvi SWA, Kumar MD, Narvekar PV, de Sousa SN, George MD, D'Silva C (1993) An intermediate nepheloid layer associated with high microbial metabolic rates and deni-

Editorial responsibility: Dittmar Hahn,

Newark, New Jersey, USA trification in the Northwest Indian ocean. J Geophys Res 98:16469-16479

Naqvi SWA, Jayakumar DA, Narvekar PV, Naik H, Sarma VVSS, D'Souza W, Joseph S, George MD (2000) Increased marine production of $\mathrm{N}_{2} \mathrm{O}$ due to intensifying anoxia on the Indian continental shelf. Nature 408:346-349

Nogales B, Timmis KN, Nedwell DB, Osborn AM (2002) Detection and diversity of expressed denitrification genes in estuarine sediments after reverse transcription-PCR amplification from mRNA. Appl Environ Microbiol 68: 5017-5025

Prieme A, Braker G, Tiedje JM (2002) Diversity of nitrite reductase (nirK and nirS) gene fragments in forested upland and wetland soils. Appl Environ Microbiol 68: 1893-1900

Rosch C, Mergel A, Bothe H (2002) Biodiversity of denitrifying and dinitrogen-fixing bacteria in an acid forest soil. Appl Environ Microbiol 68:3818-3829

Shetye SR, Gouveia A, Shenoi SSC, Michael GS, Sundar D, Almeida AM, Santanam K (1990) Hydrography and circulation off west coast of India during the Southwest Monsoon 1987. J Mar Res 48:359-378

Song B, Ward BB (2003) Nitrite reductase genes in halobenzoate degrading denitrifying bacteria. FEMS Microbiol Ecol 43:349-357

Song B, Palleroni NJ, Haggblom MM (2000) Isolation and characterization of diverse halobenzoate-degrading denitrifying bacteria from soils and sediments. Appl Environ Microbiol 66:3446-3453

Spinrad RW, Glover H, Ward BB, Codispoti LA, Kullenberg G (1989) Suspended particle and bacterial maxima in Peruvian coastal waters during a cold water anomaly. DeepSea Res 36:715-733

Swallow JC (1984) Some aspects of the physical oceanography of the Indian Ocean. Deep-Sea Res 31:639-650

Thompson JD, Gibson TJ, Plewniak F, Jeanmougin F, Higgins DG (1997) The ClustalX windows interface: flexible strategies for multiple sequence alignment aided by quality analysis tools. Nucleic Acids Res 24:4876-4882

Waibel AE, Peter T, Carslaw KS, Oelhaf H and 6 others (1999) Arctic ozone loss due to denitrification. Science 283: 2064-2069

Ward BB, Hogan ME, Jayakumar A, Naqvi WA (1998) Denitrification parameters in the Arabian Sea. EOS Trans Am Geophys Union 79:OS83, January 1998. American Geophysical Union, Washington, DC

Yan T, Fields MW, Wu L, Zu Y, Tiedje JM, Zhou J (2003) Molecular diversity and characterization of nitrite reductase gene fragments (nirK and nirS) from nitrate- and uraniumcontaminated groundwater. Environ Microbiol 5:13-24

Zumft WG (1997) Cell biology and molecular basis of denitrification. Microbiol Mol Biol Rev 61:533-616

Submitted: April 25, 2003; Accepted: July 23, 2003

Proofs received from author(s): December 9, 2003 